\title{
The Ottoman Empire's Escalation from Reforms to the Armenian Genocide, 1908-1915
}

In the first decade and a half of the twentieth century, Ottoman treatment of its Armenian community changed in step with changing threats to the polity. The Armenian nation had no pivotal secessionist "moments" as such during this period. Rather, the state of Armenian demands and nationalism was a near constant phenomenon: significantly greater autonomy, up to and including statehood. As we shall see, the Ottoman response to these Armenian demands ebbed and flowed. Upon deposing the sultan and assuming power in 1908, the Young Turk movement dealt with the Armenians peacefully, with the promise of administrative reforms. However, once World War I broke out, and Turkey joined the Central Powers, the Armenians faced genocide. Seven years apart, the same regime, facing the same ethnic group, used strategies as vastly different as "negotiations and concessions" and "collective repression." Why?

The increased external vulnerability brought about by Turkey's involvement in the war was crucial in the escalation the Armenians faced, particularly given relations between Russia, the Ottoman state, and the Armenian community. When the Young Turks first rose to power, they had a relatively optimistic outlook on the state's future in Europe. More important, they conceived of Ottoman identity as including the presence and participation of Armenians. These beliefs supplied the confidence necessary for a strategy of negotiations and concessions. However, by 1914-15, their treatment of Armenians changed dramatically, with two factors relating to external security especially relevant. First, the changing shape and form of the Ottoman Empire between 1908 and 1914-it lost essentially all of its European territory-meant that the state's identity became based more on a narrow Turkism than an accommodating Ottomanism. Shifts in Ottoman identity ensured that Armenian nationalism was no longer considered indifferent to the national core but actively opposed to it and caused the regime to view Armenian demands in a more 


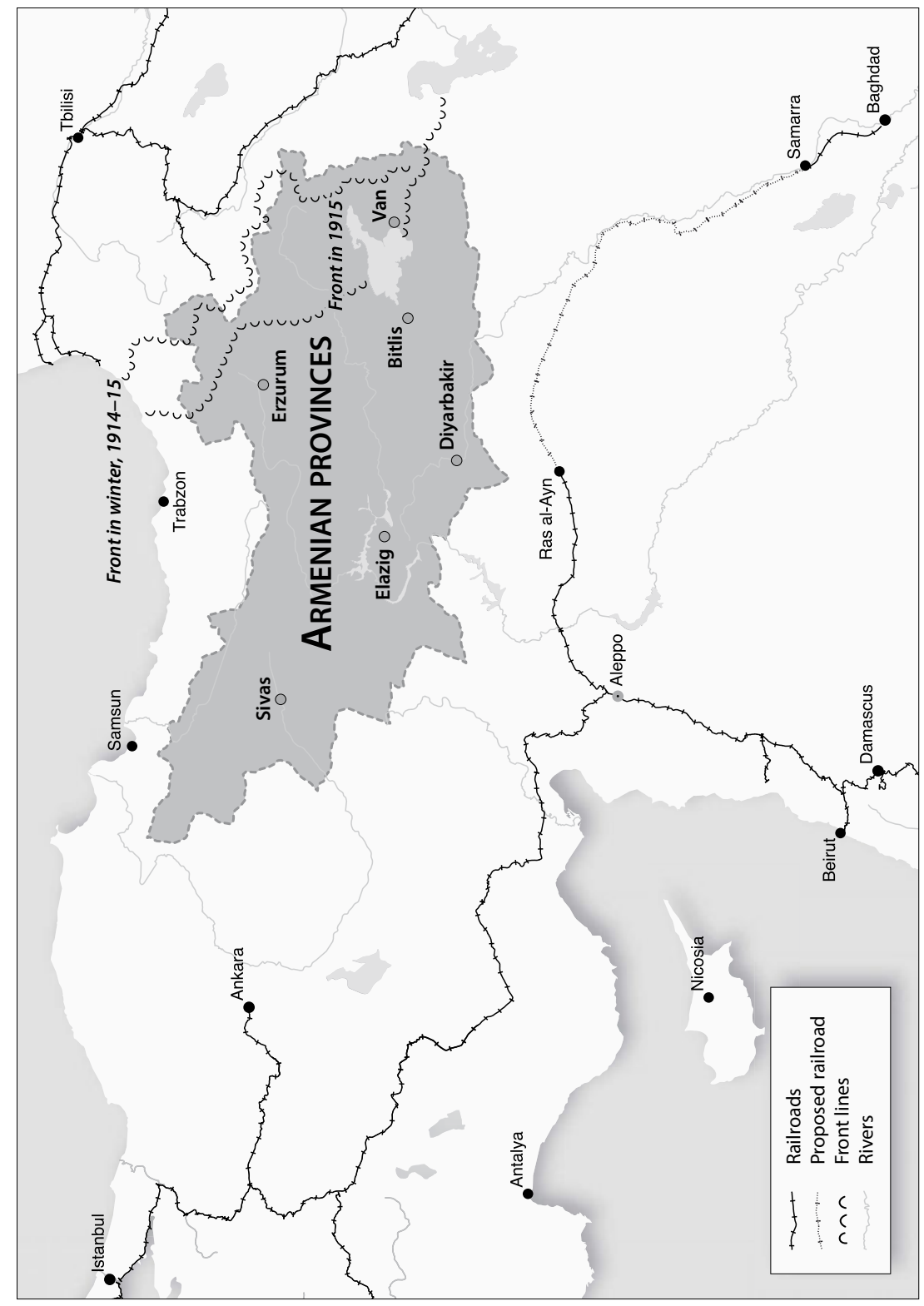

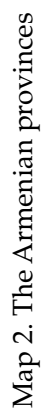


existentially threatening light. Second, the fact that the Ottomans and Russians were on opposite sides in the war meant that when the latter's support for Armenians shot up, it did so at a time when the very survival of the Ottoman Empire was in peril. Strong support by Russia for the Armenians had both material and emotional consequences, whereby the Ottoman Empire faced a significantly tougher fight in World War I thanks to Armenian collaboration and acted angrily in the face of perceived betrayal. In conjunction, these factors-the adoption of a more exclusivist and paranoid nationalism by the Young Turk regime, which shifted the identity distance between the two groups from "indifferent" to "opposed," and "high" Russian support for the Armenians during the Great Wartranslated into genocide.

I believe this case is worthy of investigation for a number of reasons. First, "extreme" cases, or those where either or both of the independent and dependent variable lie far from the median, can prove instructive. ${ }^{1}$ The Ottoman-Armenian case certainly fits this description, with state strategy spanning from "negotiations and concessions," wide-ranging and substantive reforms to the Armenians, to "collective repression." Insofar as the independent variable is concerned, it is difficult to imagine a more externally threatening environment than the one the Ottoman Empire faced during World War I.

Second, because the Ottoman case was not one of a modern nation-state, but an empire in the midst of dissolution, its inclusion increases the breadth of the sample tested thus far. Unlike most other European empires-the British, French, Dutch, Portuguese, and Spanish—the Ottoman Empire was geographically contiguous, with no body of water between the metropole and the periphery. This meant that it "looked" like a state more so than the Western European empires (see chapter 1).

Third, scholars suggest dividing a single case into two subcases, a technique known as "before-after research design," in order to gauge the effects of changes in one significant variable. ${ }^{2}$ Leveraging the variation in Young Turk strategy with respect to the Armenians in 1908 and 1915, when little about the case changed other than the appreciably different external environment the state faced, allows for a fruitful examination of the effect of external security conditions on state strategy with respect to separatist minorities.

Before proceeding, it is important to note that the historical origins of the Armenian genocide are strongly contested. As the title of one book suggests, the Armenian genocide is a "disputed genocide." ${ }^{3}$ There are essentially two interpretations on what transpired between the Ottoman state and its Armenian nation. First, there is the belief that, absent World War I, the Armenian genocide could not and would not have happened. This view is generally forwarded by Western historians, who argue that the Ottoman position and performance in the war was intimately tied to its decision to organize the deportations of hundreds of thousands of people in bad 
weather and through rough terrain, without protection against marauders or disease, resulting in the murder of a million Armenians. The oppositional view, generally forwarded by Armenian historians, is that the genocide was a premeditated act, planned well before World War I. ${ }^{4}$ There is a third view, proffered primarily by "official" Turkish historians, ${ }^{5}$ who argue that there was no deliberate mass-targeting of the Armenian community in the first place, ${ }^{6}$ and to the extent that there was violence committed against Armenians, it was part and parcel of the fog of war. Such "scholars" understate levels of violence against the Armenians; ${ }^{7}$ overstate Armenian responsibility for the violence; claim that rather than ordering massacres, the Young Turk regime wanted to provide both food and security to the deportees; ${ }^{8}$ argue that the Armenians suffered no more or less than other communities in the state during the Great War; and practice frankly bizarre forms of false equivalence, where small-scale incidents such as murders and seizures of banks occupy the same moral space as the deaths of hundreds of thousands of people. ${ }^{9}$ This third view has been thoroughly discredited, and as such, I will not engage with it at length here, except to merely note its existence.

I side primarily with the first camp. Although the leadership in the Ottoman state may well have harbored considerable ill-will toward their Armenian citizens before the war and was uneager to ensure their safety once deported, it was only the security exigencies of the Great War that caused the genocide. In particular, the real and perceived partnership between Russia and the restive Armenian population made the senior Ottoman leadership believe that their prospects of survival in the war were nonexistent if they did not first tackle the Armenian "problem."

The main factors to consider in favor of this argument are: the perilous situation the Ottomans found themselves in the spring of 1915; the location of major Armenian population centers, occupying important territory along Ottoman lines of communication and supply as well as possible lines of Russian invasion; and the timing and escalation of the major deportation orders by Talaat and Enver Pasha. As we shall see, Armenian population centers were concentrated in the Ottoman rear, especially with respect to two of their three major fronts in World War I-the Caucasus campaign against Russia and the Palestine and Mesopotamian campaigns against Britain. During the spring and summer of 1915, when the Ottoman Empire was considered to be on its last legs, and faced Allied and Russian incursions in three theaters as well as internal insurrections, its leaders ordered deportations both when and where it faced the greatest security threat. In conjunction with corroborating public and private testimony from the main Ottoman decision makers, the implication is that the Ottoman state was concerned with the prospect of the Armenian fifth column attacking its vulnerable supply and communication lines, or alternatively, joining advancing Russian or Western forces, both fears that were realized in a number of 
cases. On a wider temporal scale, the onset of the war, and considerable territorial losses in the years running up to it, at once solidified the existence of threats emanating from abroad, and hardened Ottoman resolve to deal with them.

For the purposes of the general argument forwarded in this book, then, external security considerations for the Ottoman state were the crucial driving variable for the escalation from its accommodationist policy to widespread slaughter. In 1908, the revolutionary Young Turk government attempted "negotiations and concessions" to solve the Armenian issue because they had an optimistic view of the state, both internally and externally. By the time the war began, however, and the external threat that the Ottoman state faced ramped up due to changes in national identity and the wider geopolitical context, its policy of "collective repression" was put in place. Figure 4 summarizes the argument I forward in this chapter.

The main theoretical alternatives to mine outlined in the introduction cannot explain the observed variation in this case. The reputation argument

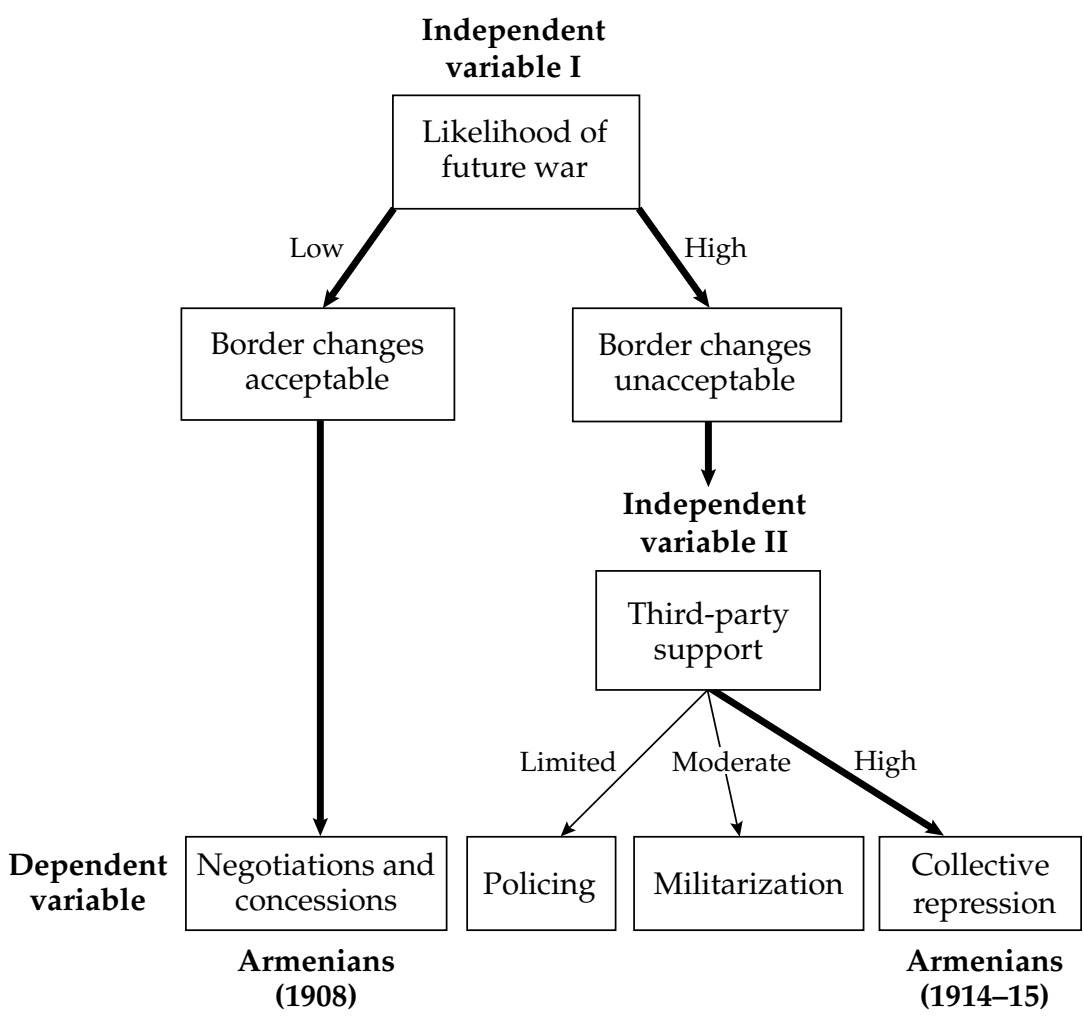

Figure 4. Variation in the Ottoman Empire's treatment of Armenians, 1908-15 
would predict that the earlier movement would face greater violence, but the opposite took place. Meanwhile, Young Turk leaders' concentration of power between 1908 and 1915 would have been relevant for the veto points argument-as long as they preferred a policy of concessions, only to be stymied by a lack of credibility with the minority. However, in the spring of 1915, the Young Turk leaders were flatly uninterested in concessions to the Armenians, rendering theories centering on domestic institutions less than useful in explaining the Ottoman escalation to genocide. The main alternative, context-specific argument would be that external security considerations were merely correlated, rather than causally related, with Ottoman decision-making, and that the leadership had decided on genocide well before the Great War. Such a view does not withstand empirical scrutiny, as we shall see.

\section{Antecedent Conditions of a Tripartite Rivalry}

In the early 1800s, historic Armenia was scythed up between the Russian and Ottoman empires, and the Russians supplemented those gains in the coming years by snapping up territory through wars, conquests, and treaties. ${ }^{10}$ By the middle of the century, the Ottoman state was left with just over 2 million Armenians under its control, more than half of which lived in six vilayets, or provinces: Van, Bitlis, Erzurum, Diyarbakir, Kharput, and Sivas, where they outnumbered both ethnic Turks and Kurds. Armenians were also concentrated on the Mediterranean coast at Cilicia. ${ }^{11}$ The geographic distribution of Armenians mattered greatly because the Ottoman authorities, in trying to dampen calls for reform, would attempt to minimize the number of Armenians in particular areas. ${ }^{12}$

Armenian demands in the latter half of the nineteenth century had not yet escalated to full independence. Rather, they sought guarantees of life and property. Armenians often fell victim to marauding Kurds, who would attack entire villages and extort local merchants. This practice forced a system of double taxation on Armenian communities, who paid high taxes to the state on account of being non-Muslim, even before they were subjected to violence and intimidation from Kurds. Moreover, the laws and regulations of the Ottoman system imposed additional hardships on the Armenian community: Christians were not equal before the law and judicial system, and they were barred from serving in the higher levels of the government and military. Worse still was that the perpetrators of attacks against them were never punished, which in turn encouraged yet more attacks. In fact, the Turkish-Armenian conflict actually began as a KurdArmenian conflict; the latter were generally defenseless against Kurdish violence and extortion, and it was the refusal of Ottoman authorities to do anything about it that greatly angered the Armenians. ${ }^{13}$ 
The Armenian community was generally more economically advanced than most ethnic blocs under the Ottomans. In this, they were aided by the fact that Muslims in the state were discouraged from merchant or tradereliant careers. Moreover, the Armenians' geographic clustering and religious identity led to a stronger sense of nationhood and common identity than among most other groups. As a consequence, it was easier for them to forward demands as a unified community in the face of discrimination. Reform on security, administrative matters, taxes, and property were the central Armenian demands in the latter half of the nineteenth century, with independence or autonomy not a major concern as yet. ${ }^{14}$ From the state's point of view, the Armenians were not considered the most pressing internal problem either, to the point that they were famously considered the "most loyal community" among Ottoman Christian citizens in the nineteenth century. ${ }^{15}$

In 1877, war broke out between Russia and the Ottoman Empire. The Ottomans allied with Britain, which itself was wary about Russian ambitions in and around Asia Minor, Persia, and India. However, Britain's support did not extend to lending a military hand to the sultan, and Russia won the war relatively easily. In fact, they entered Constantinople and were six miles from the Porte before French and British forces compelled the Russians to stop their advance. The war resulted in Russia annexing the border regions in the Caucasus. The 1878 Treaty of Berlin marked the end of the war, and with it ensured independence for Serbia, Montenegro, and Romania-that is, the Ottomans lost most of their Christian citizens. In addition, Bulgaria won greater autonomy and reforms were promised to Macedonia, eastern Roumelia, Salonika, and Kosovo. ${ }^{16}$

These developments reaffirmed Ottoman perceptions of Russia seeking to weaken it from within by supporting the independence efforts of ethnic groups in their midst, particularly if they were Christian. ${ }^{17}$ More generally, they fueled resentment at Western intervention in the state's domestic affairs. ${ }^{18}$ Russia's actions did not allay these concerns. It put its cards on the table when it pledged to withdraw from annexed Ottoman territory only when reforms targeting Armenian grievances were put in place. ${ }^{19}$ Perversely but unsurprisingly, international intervention in Armenian efforts toward reform provided mixed results at best-while the recognition of their strife led to a greater sense of national consciousness among the Armenians, European interference tended to give the Ottoman leadership more reason to clamp down on them. ${ }^{20}$

Russia's ambitions for Ottoman Armenians were not very grand or wide ranging. Contrary to Ottoman perceptions, Russia did not prefer Turkey's empire to dissolve or be partitioned out of existence; rather, Russia preferred a weak but still viable Ottoman state. With regard to Armenian aspirations, Russia wished for the sultan to enact relatively moderate reforms-concessions too weighty would be problematic for the Russians 
too, since they had their own politically active Armenian minority. ${ }^{21}$ Although Russia's geostrategic focus turned partly from the Balkans and Near East to Persia and the Far East, it still considered its "historic" tasks in the Near East important. These objectives were that no third state should control the Straits, which were key for Russian commerce, and a natural launching point for control of the Balkans and the Black Sea; statehood for Balkan Christian peoples; and a general, non-negotiable sphere of influence in the Near East.22

Regardless of Russian interference and provocation, when the Young Turks rose to power, their first interactions with Armenians were hardly marked by antipathy, or anything close to it. To the contrary, their relationship was, at least at the outset, marked by cooperation and mutual optimism.

\section{Young Turks Ascension to Power and Accommodation of Armenians}

The Young Turks assumed control of the state in a revolution in 1908 that featured "astonishingly little bloodshed." ${ }^{23}$ The revolutionaries were an eclectic group: modern thinkers, intelligentsia, liberals, and naval and military officers, organized under various political groups, most prominent of which was the Committee of Union and Progress (CUP). The CUP was inspired by the French Revolution and Japan's Meiji Restoration, which imparted to the Young Turks the lesson that constitutionalism was the key to state strength. In this simplistic view, constitutionalism was considered a panacea, "a recipe for alleviating ethnic strife, ending nationalist separatist movements, propelling economic growth, and instituting legal rationality in the military and the civil administration." ${ }^{24}$ The organizational antecedent for the Young Turks was the Ottoman Union, a secret group formed in 1889 by medical students in Istanbul, which operated underground and worked to establish contacts with liberal-minded members of the sultan's regime as well as oppositional figures abroad, particularly in Western Europe. Ahmed Riza was the main leader in charge of the organization that was to develop into the CUP. ${ }^{25}$ Riza was based in Paris-many of the Young Turk movement's leaders resided abroad-and led calls for constitutionalist government. He also decried foreign interference in Turkey's internal affairs. ${ }^{26}$ Additionally, dissatisfied military officers were an important component of the Young Turks and the CUP. One scholar has characterized the entire transition to constitutionalism as "overwhelmingly military in character" and the revolution as "the corroboration of the ideas and activities of a handful of idealists who leaned upon the military for its prompt and smooth execution." ${ }^{27}$

The Young Turk movement had been the subject of persecution from the sultan's regime throughout the 1870s and 1880s but its organizational 
strength and activism grew in the 1890s to the point where it was a latent revolutionary threat to the regime. ${ }^{28}$ The elements behind the Young Turks even attempted a coup in August 1896 but were thwarted at the last moment, throwing their entire secret organizational structure into chaos and forcing a temporary retreat. ${ }^{29}$ The Young Turks finally staged their revolution in 1908, with July 24 signifying the end of autocratic rule and the beginning of the era of the Second Constitution. ${ }^{30}$ Ideologically, what united the movement was their common goal of a comprehensive modernization program and a fervent belief in Ottoman nationalism and identity, building on ideas first carried forward by the Young Ottomans. ${ }^{31}$ Their principal aim was to restore the constitution and depose the sultan's government, which was too theocratic and regressive for their modernist world view. ${ }^{32}$

Even before their revolution, the Young Turks had foreshadowed a spirit of cooperation that was to mark their relationship with Armenian nationalists in 1908. Despite differences of opinion, representatives from nationalist parties such as the Hanchaks, including Stepan Sapah-Gulian, M. Boyadjian, and Arpiar Arpiarian, met with Young Turk leaders Nazim and Behaeddin Shakir. As Kirakossian writes, the two sides found a mutually beneficial framework: the Young Turks "agreed with the idea of establishing autonomous Armenia: she was not to be separated from Turkey but could have a European governor. . . Ahmed Riza and others expressed readiness to meet Armenian requirements on the condition that Huntchaks assist in resolving general state problems." ${ }^{33}$ Consistent with these expectations, when they finally rose to power, the Young Turks dealt with the Armenian community peacefully. Their strategy was rooted in both a reasonably secure regional environment and, more importantly, a belief that Armenians were an important component of Ottoman national identity.

The Young Turks assumed power with the wholehearted support of the two main Armenian revolutionary parties, the Hanchaks and the Dashnaks. ${ }^{34}$ In terms of their goals, the Hanchak Party was more radical than the Dashnaks, who unlike the former group, did not advocate for full-blown independence, but rather reform within the empire. ${ }^{35}$ Though there was much to unite the elements that made up the nascent state, there was one important division, which was to matter a great deal a few years down the road. Specifically, how would the state be organized administratively? Ahmed Riza called for greater centralization, while the decentralist group, which was led by Prince Sabahaddin, the sultan's nephew, called for political and economic liberalization along the Anglo-Saxon model. ${ }^{36}$ The Armenian community, naturally, supported the Sabahaddin camp. ${ }^{37}$

At the time, however, Armenian nationalists and the Young Turks put their differences aside. It was not just a common foe that united themthough it remains trivially true that neither had any love lost for the sultan. Rather, the promise of a constitution and a more modern Ottoman Empire held appeal for each set of ideologues, the Armenian nationalists 
as well as the Ottoman state builders. This was why "Armenians took great satisfaction in the victory of the army and its CUP commanders.... The downfall of the sultan and the restoration of the constitution of 1876 was everything and more that they and their parties such as the Dashnaks had hoped for." 38

In the aftermath of the July Revolution, the CUP reached out to all nonTurkish communities, including the Armenians, Greeks, and Macedonians, to institutionalize cooperation on the question of candidates for the upcoming elections, bringing them into the CUP fold. ${ }^{39}$ From the perspective of the CUP, it was imperative, right from the beginning, to portray a friendly and tolerant image toward the Christian communities within the empire and to do away with internal divisions. Their message was clear: the aim was a constitutional regime, and all communities organized against the sultan's regime were not just welcome but necessary. ${ }^{40}$ To that end, the Young Turk regime's initial months were marked by greater liberalization in the entire state, including lifting censorship of the press, disbanding the sultan's internal intelligence network, amnesty for political prisoners, and the dismissal of corrupt government and palace officials. ${ }^{41}$ Citizens of "all denominations marched in the streets under banners bearing the slogan 'Liberté, Egalité, Fraternité' in various languages, and welcomed the age of freedom and democracy." 42

Aside from this general trend of liberalization, the Young Turks made several substantial concessions to the Armenian community. Armenians contested seats in parliament, as full Ottoman citizens of the state, rather than as part of a separate millet, or nation. The Armenian national assembly was convened after being banned under the sultan. Schools and libraries were opened, and newspapers were allowed to circulate. Kurdish raids and violence were scaled down. Exiled notables, such as the deposed patriarch of Constantinople, Madteos III Izmiriliyan and the writer Grigor Zohrap, were welcomed back home. Enver Pasha, Talaat, and other Young Turk leaders went to Armenian churches, schools, and graveyards, where they paid respects to fallen Armenians who had died in the antisultan struggle, and made powerful speeches pointing to cooperation between Turks and Armenians. Enver told "children that the old days of Moslem-Christian strife had passed forever and that the two peoples were now to live together as brothers and sisters." The changes that took place were slow moving, but they were substantive, and recognized as such-even by revolutionary Armenian parties. ${ }^{43}$ The Hanchaks went so far as to claim that the Ottoman parliament was a "genuine spokesman of the yearnings and will of the subjugated element, staunch supporters of its human rights and the champion of the fatherland's freedom." ${ }^{44}$ Sapah-Gulian, one of their leaders, wrote that "when the constitution was proclaimed, the majority of Armenians and myself among them, became Ittihadists. Our common belief was that the party that proclaims the constitution is heart and soul for the progress 
and development of the entire country and all her people." ${ }^{45}$ Parties such as the Dashnaks would participate fully in Ottoman politics, cooperating with the CUP, playing an active role in the first parliamentary elections, and mobilizing Armenian support in favor of the constitution. ${ }^{46}$ As Suny summarizes, "The 1908 revolution proclaimed a new era for the empire, a progressive step into a European-style modernity based on constitutionalism, equality, fraternity, and personal freedom," and therefore "Ottoman Armenians and other minorities joyfully greeted the restoration of the liberal Constitution, hopeful that the new government would provide a political mechanism for peaceful development within the framework of a representative parliamentary system." 47

CUP's rhetoric and actions spoke to the accommodationist stance they held toward the Armenian community in the early days of their regime. To use my theoretical framework, the state used "negotiations and concessions" when dealing with Armenian demands for autonomy. This strategy was undergirded by confidence in their future security; Young Turk leaders were not preoccupied with foreign relations but sharply focused on internal reform. They could maintain such a focus first because they had a base optimism about the future of the Ottoman Empire. Specifically, in 1908 "the Young Turks believed in the possibility of their empire's becoming a full member of European international society, convinced that it could represent the harmony of Eastern and Western civilization," and went about cultivating diplomatic contacts in various European capitals, seeking to cement friendships with major powers such as Britain, France, and Germany. ${ }^{48}$

More important than this optimism about their regional environment, the Young Turks' conceptualization of Ottoman identity was consistent with, and welcoming of, the presence of Armenians, and called for their greater political participation. The Armenian and central leaderships shared ideological goals, and Armenian demands for autonomy were not seen as unreasonable or problematic. The basic belief upholding their reforms was that if the Ottoman Empire could unite its various nationalities from within, its relations with Europe and the world would, in essence, take care of itself. For the Young Turks, unlike previous Ottoman regimes, Armenian identity was not "opposed" to that of the central state, but "indifferent."

Ottoman nationalism, particularly in the early period of the Young Turk regime, implied the privileging of Ottoman identity over and above communities' parochial identities. As Kayali notes, "In the euphoria of July 1908 the Unionists believed that the non-Muslims would be won over to the CUP's Ottomanist platform in the new parliamentary regime. They hoped that religious and ethnic differences would be superseded by a broader Ottoman identity." 49 In other words, Ottoman concessions to Christian communities generally and the Armenians specifically grew out of a 
belief that all Ottoman citizens owed their allegiance to the state, and as such, their primary identity should be tied to it. The antecedent arrangement of separate millets, or nations, starkly recognized, and contributed to, the ethnic differences between different groups of Ottoman subjects, ${ }^{50}$ distinctions which the Young Turks aimed to extinguish. This shift in worldview mirrors the so-called soup versus salad debate on immigration in contemporary politics, where some advocates argue that all communities must subjugate themselves to a larger identity, as ingredients mix in a melting pot of soup, while others argue for the maintenance of (respectful) boundaries between different ethnic or religious groups, akin to vegetables in a salad bowl, such that each maintains their unique character in a larger ensemble. ${ }^{51}$

The Young Turks initially opted for a soup model. As Enver Pasha memorably claimed, "We are all Ottomans." The general philosophy they espoused was one of unity "without distinctions of race" and the "peace and safety of the common homeland" alongside the abandonment of "particular purposes." The state would be organized along the "secular and universalist principle of the equality of all subjects, who all owed equal loyalty to the empire." 52 As the CUP wrote to one Bulgarian politician, "This country belongs neither to the Turk, nor to the Bulgarian or Arab. It is the asset and domain of every individual carrying the name Ottoman. ... Those who think the opposite of this, namely those who try to sever the country into parts and nations, even if they are Turks, are our adversaries, our enemies." 53

This fervent belief in Ottomanism is referred to by detractors of the regime as "fascist," but in reality, the Young Turks were simply behaving as other European powers, where the creation, imposition, and sustenance of national and uniform identities became state projects. ${ }^{54}$ Nationalism, as it existed in contemporary Europe, swept into the Ottoman state around the middle of the nineteenth century, and came hand in hand with a more general belief in transporting the dominant ideas about politics at the time, from reforms aimed at strengthening the bureaucratic nature of the state, to the liberalism of Montesquieu, Rousseau, and Smith. ${ }^{55}$ It was the very lateness of this arrival of nationalism that forced on the Young Turks such decisions about the "official" state identity. ${ }^{56}$

Terms such as centralism and decentralization, therefore, should be treated with caution, as they are often taken to mean things that they do not. For instance, it would be easy to fall into the analytical trap of conflating "decentralization" with positive reforms toward the Armenian community. In fact, centralist ideas lay behind the concessions: the notion that all citizens were Ottomans first and foremost meant that the CUP was eager to ensure equality in treatment. For the Young Turks, Armenian nationalism was not opposed to Ottoman identity, it was to be seamlessly subsumed under it. 
The Young Turks' view of their national identity, which had a welcome place for the Ottoman Armenian community, when combined with the relatively relaxed external environment the state faced in 1908, opened the possibility of significant concessions. Soon, however, both the Ottoman Empire's regional security, as well as its conception of Armenian nationalism, would undergo drastic changes-with severely deleterious consequences for Armenians.

\section{Radicalized Identity, Deteriorating Neighborhood}

The spirit of bonhomie and mutual cooperation between the Young Turks and the Armenian community lasted less than a year. The 1909 Adana massacre, where roughly twenty thousand to thirty thousand Armenians died following a temporary countercoup by the sultan, and the general slow pace of reform notwithstanding promises to the contrary, put paid to Armenian hopes. For their part, the Young Turks' view of the Armenian community would also change drastically over the next half-decade, with two episodes particularly responsible.

First, the Ottomans' defeats in the Balkan wars of 1912 would irrevocably change both the physical and ideological nature of the state. Losing its European and Christian territories meant that the Ottoman Empire pursued an increasingly Turkified nationalism, as a result of which Armenian identity assumed a much more sinister and threatening shape. These developments caused the shift in Ottoman perceptions of Armenian identity from "indifferent" to "opposed." Second, the 1914 Mandelstam Plan, named after a Russian diplomatic official, which called for Armenians' autonomy being guaranteed by foreign powers, mainly Russia, cemented in the leadership's collective mind that Armenian nationalists were a fifth column not to be trusted. Together, these developments ensured that the Ottoman leadership began to see Armenian nationalism as a significant security threat, one whose dangers escalated drastically once World War I broke out and Russian support for Armenians rose to "high" levels.

THE BALKAN WARS' TERRITORIAL AND

IDEOLOGICAL CONSEQUENCES

The first major episode that shifted Young Turk perceptions of Ottoman Armenians was the Balkan wars. In October 1912, Serbia, Montenegro, Greece, and Bulgaria declared war on the Ottoman state. "Out-powered, demoralized, unprepared, and poorly equipped, the Ottoman army fought fourteen battles and lost all but one of them." ${ }^{57}$ Within a few years, due to war losses and successful separatist movements, the Ottomans lost about 40 percent of its landmass and about 25 percent of its population. The first 
domino to fall was Bulgaria, which declared its independence, followed by Austria-Hungary's annexation of Bosnia and Herzegovina. Having fought a war against Italy in 1911, due to which the Ottomans lost Libya, the Balkan wars in 1912 ensured that Turkey was essentially no longer in Europe..$^{58}$

What proved pivotal was not just the extent of territorial loss, but also its nature. Having lost almost all its European and Christian territories, the multinational and multiethnic character of the state lay in tatters, moving the center of gravity of the Ottoman Empire east, toward Anatolia. The Balkan provinces had been the "heart of the Empire, its provinces being by far the most advanced and the most productive. They had always provided much of the Empire's wealth and had long been the recruiting ground for the army and the bureaucracy." 59 This was no longer the case. The loss of European territories precipitated a crisis for the Ottoman state; one scholar claims that "it is no exaggeration to state that the effect of the Balkan wars on Ottoman society was nothing short of apocalyptic." 60 There were a number of reasons for this.

First, and most important, the territorial losses and European opportunism narrowed the Young Turks relatively pluralistic Ottomanist ideology to one espousing Turkish identity and nationalism. ${ }^{61}$ After all, simple demographics meant that with the exit of the Albanians, Greeks, and Slavs, the Turks were numerically dominant in a way that they were not before 1908. Moreover, the very fact of territorial losses "strengthened the hands of centralizers and of Turkish nationalists/Islamicists against liberals and Christians-a stronger, more loyal state was needed." ${ }^{62}$ As a consequence, the state saw a transition, from the "seemingly liberal, egalitarian Young Turks into extreme chauvinists, bent on creating a new order." 63 One exemplar of this trend was Ziya Gökalp, one of the key intellectual and ideological figures behind the new Young Turk movement, who believed that state strength comes from homogeneity. A nation, he wrote, "must be a society consisting of people who speak the same language, have had the same education and are united in their religious and aesthetic ideals-in short those who have a common culture and religion." ${ }^{64}$

This paradigmatic shift in the regime's conception of the state's identity would have significantly adverse consequence for the Armenian community down the road. Armenians were now perceived as directly opposed to the Ottoman national core, after previously being seen as unthreatening to, and being subsumed under, it. As Bloxham notes, what eventually drove the Armenian genocide was the "the impulse 'to streamline, make homogenous, organize people to be uniform in some sense. . . CUP nationalism was . . shaped by, and in reaction to, the ethno-nationalist movements in the Balkans." ${ }^{65}$ Melson concurs, noting that "by 1912, certainly by 1915, the Young Turks were not particularly benign or dedicated to pluralism. They had become xenophobic integral nationalists for whom the identity and 
situation of the Armenians were sufficient proof of their treachery and potential threat to the continuity of the empire." 66 War losses generated a significant shift in the Young Turks' outlook on questions of identity.

Second, the Balkan losses increased the salience of any seditious activity in Anatolia, which now constituted the Turkish heartland. ${ }^{67}$ As Abdullah Jevdet, a CUP leader, said: "Anatolia is the well spring of every fiber of our life. It is our heart, head, and the air we breathe." ${ }^{\prime 8}$ The Young Turks considered disloyalty from its secessionist citizens as the primary cause of military defeat. The positive reforms they had instituted had, in a sense, sown the seeds of the state being scythed up.

More than the failure of the Ottoman army to mobilize and defend the empire, many observers saw treason at the heart of this tragic defeat. Local Christian civilians and armed bands in Macedonia had aided the onslaught of the Balkan States. The eviction of hundreds of thousands of Ottoman Muslims from Macedonia and Kosova entailed the forfeiture of countless homes and hectares of land to the Christian victors. Ottoman Christian subjects still under Istanbul's rule were not immune to blame ... the complicity of both Christian and Muslim Albanians in establishing an independent Albanian state in November 1912 confirmed to many in the government the duplicity and seditiousness of their former countrymen. ${ }^{69}$

Finally, the losses in the Balkan wars led to the predominance of external security concerns for the CUP, which "weighed heavily on the minds of the Young Turks immediately after the fighting ended." ${ }^{\prime 70}$ No longer was the neighborhood deemed safe enough to risk policies that could result in border changes. The losses in the Balkan wars created a "new sense of crisis" for the state and its Committee of Union and Progress leadership. ${ }^{71}$ As Üngör argues, the issues of external security, a more fervent Turkish nationalism, and ethnic separatist mobilization were inextricably bound up with one another:

Most of all, the Young Turks' perception that the catastrophe of the Balkans should never be allowed to happen to the remaining territories of the Ottoman Empire, especially the eastern provinces, would give birth to unprecedented forms of population politics and social engineering. One major outcome of these processes was a deep fear, or perhaps a complex, of loss. The fear of losing territory was a persistent phobia of both late Ottoman and Turkish political culture. ${ }^{72}$

Crucially, this increase in levels of fear the regime faced was directly due to the behavior of outside powers. As the U.S. ambassador during the war noted in his memoirs, "Of all the new kingdoms which had been carved out of the sultan's dominions, Serbia ... is the only one that has won her own independence. Russia, France, and Great Britain have set free all" the other 
Christian peoples in the Ottoman Empire. ${ }^{73}$ The realization of external vulnerability led the triumvirate of Enver, Talaat, and Jamal to make military restoration a serious priority on reasserting strong control of the Ottoman state in 1913. They wished to modernize the military corps, increase their spending on defense, acquire better equipment, and build modern naval ships. They also recruited German officers, thought to be the best officer corps in Europe, for army training purposes, as well as the British and French for the navy and reorganizing the gendarmerie respectively. The Russians, owing to the transparency of their designs on Ottoman territory, were not considered. ${ }^{74}$

Turkey's territorial losses in the Balkan wars were significant from the point of view of the Armenian nationalists too, serving as valuable learning experiences. They thought great powers might help resolve their national question just as had been the case with other Christian peoples under the Ottomans. ${ }^{75}$ An article in a Russian newspaper argued that "all the Turkish Armenians regardless of their membership of a party ... see Russia as their sole defender and savior and are envious of the peaceful life of the Russian Armenians." 76

In sum, the losses in the Balkan wars made the Young Turks more wary of external security concerns, more suspicious of any secessionist activity in its homeland, and more narrowly nationalistic in its outlook. Territorial losses changed how the ruling regime saw the state as well as how it saw the Armenian community: identity relations shifted from "indifferent" to "opposed." Moreover, all these changes took place in an environment of internal upheaval for the CUP. ${ }^{77}$ Within this context of geopolitical weakness-a shrinking state facing ethno-nationalism from within and, from without, rapacious European powers with whom it suffered an imbalance of economic and military power-the Armenians and Russians pushed for a reform plan. ${ }^{78}$ The Mandelstam Plan hammered the nail in the coffin of Ottoman-Armenian relations.

\section{THE MANDELSTAM PLAN}

By the time the Balkan wars were over, the Armenians had essentially given up on eliciting concessions from the Turks without external intervention, their hopes from the 1908 revolution dashed..$^{79}$ The obvious patron was Russia, whose reasons for supporting Armenian reforms were strategic. Unlike the 1890s, when they expressed greater trepidation at the prospect of Armenian independence or autonomy owing to a fear of nationalistic conflagration, Russia was more firmly behind this round. ${ }^{80}$ Previously, Russia was fearful that Armenian uprisings in the Ottoman Empire would spread to Armenian territories in Russia, a problem that it could do without. By the early 1910s, however, Russia's strategic calculus had reversed. With Western powers, including Germany and Britain, taking an 
increasing interest in the region's division of spoils, Russia became more assertive in its traditional preference for the strategic benefits of the territories in question. This was especially because Russia's main rival in Europe, Germany, was deepening its footprint in the region, with schemes for railways in Persia and greater military cooperation with the Ottomans. ${ }^{81}$ Russia also had domestic political reasons to push for reform. Russia still faced its own restive Armenian community despite some minor efforts in placating it. Russia feared that Ottoman Armenians would use the example of other beleaguered nationalities under the rule of the Ottomans, rise to independence, and attempt to include Russian Armenians in an independent state. ${ }^{82}$ To dampen their rebellious spirit, Russia wished to advance the cause of their Armenian "brothers" across the border, so as to show that they had the community's best interests at heart.

Russia therefore took the lead in designing and proposing a plan, which originated in the Armenian National Assembly, for reform aimed at Ottoman Armenians. The reform plan, named the Mandelstam Plan after the chief dragoman of the Russian embassy, was seen as a way to extend Russian influence in the region. In a secret notice sent by the Russian vice consul at Van to Russian ambassador Giers, in Constantinople, the need to take the initiative was made clear: "We must not allow Britain to oversee the realization of reforms in Kurdistan and Turkish Armenia which lie in the sphere of our political influence. A Russian protectorate for Turkish Armenians is a must; this gives the possibility for the Russian government to have a permanent influence in Turkey. This is one way to penetrate by peaceful means." 83

The Mandelstam Plan was signed between Russia and the Ottoman Empire in February 1914 after almost a year of deliberations between the two principals as well as Britain, Germany, and France. The negotiations were testy because of the stakes involved, with each power keenly aware of its interests in the region. Russia wanted to expand its influence and placate its Armenian minority; Turkey wanted to minimize foreign involvement on its territory above all else; Germany sought to gain a foothold in the region; and Britain wanted to ensure that neither Russia nor Germany gained too much. ${ }^{84}$ The plan that was finally agreed on entailed the creation of two Armenian "zones" - one in the six eastern Armenian vilayets and one consisting of Trebizond on the Black Sea-to be administered by two neutral European inspectors at the Porte. The foreign inspectors, nominated by European powers in conjunction with the Ottoman state for a term of five years, were to ensure the execution of liberalization reforms toward the Ottoman Armenian community. ${ }^{85}$ The administrators would have the right "to appoint and dismiss all officials and provisional judges" as well as "the command of the gendarmerie and the disposal of the military forces for the maintenance of order." They would govern in consort with a "consultative council," which would include European advisers. 
Armed elements of the state such as the police and gendarmerie were to be drawn from the local population, half of which were mandated to be Christians. Official Kurdish militias were to be disbanded. Both Christian and Muslim communities were granted elected assemblies for which they could nominate representatives. ${ }^{86}$

Germany, Britain, and France looked on this plan with considerable trepidation, viewing it as the first step toward the dismemberment of the Ottoman state and a violation of its sovereignty. ${ }^{87}$ During the negotiations, German ambassador Wangenheim reported in a cable that "Russia desires an autonomous Armenia ... [but] autonomy is to be thought of as one step on the path that ultimately leads to Istanbul." ${ }^{88}$ Wangenheim claimed elsewhere that "the Armenian question is the key that will open the Straits for Russia," giving a clear indication of the prevailing wisdom in Germany on affairs in Turkey. ${ }^{89}$ The plan had also called for a "regional military service" that would ensure order and stability in those regions most susceptible to uprisings, but this element was shot down by the other European powers, who saw it as a step too far. ${ }^{90}$ The accord was signed by Turkish and Russian representatives in February 1914..$^{91}$

The Ottoman leadership bristled under the external involvement in their internal affairs. In their collective mind, the Armenians were to blame for internationalizing a domestic issue, and thus causing embarrassment to the state..$^{92}$ In addition, it greatly angered them that the reform question was brought up by the Armenians at a time of great national loss for the Ottomans, who had lost considerable swathes of territory in the Balkan wars of 1912. As one minister said, the defeats in the Balkan wars had "turned the heads of Armenian politicians," who saw the confirmation of Turkey's external weakness as an opportunity to press for the redress of grievances at home. ${ }^{93}$ Moreover, the constant interference from abroad was difficult to accept for a regime that so prized its national, independent, and modern identity.

That it was the Turks' historical and traditional enemy, Russia, which was behind the chipping away of Ottoman territory and prestige only exacerbated matters ${ }^{94}$ Indeed, the CUP government saw the Mandelstam measures as Russian preparation for annexation of the six Armenian provinces and increased control of the areas bordering Persia. As an editorial in the regimeaffiliated newspaper Tanin put it, "Europe's intervention and Europe's desire to control our internal affairs is a warning to us to ponder the fate not only of Rumelia [Balkans], but also eastern Turkey, for it will be impossible to spare eastern Turkey the fate awaiting Rumelia." ${ }^{95}$ Simple geography played a key role; "the fact that the Christian communities who revolted lived in the border regions of the Empire and that Empire progressively lost territories from the border regions were primary factors determining the policies" of the regime.${ }^{96}$ Armenian allegiance with Turkey's "national enemy" in humiliating the Ottomans ensured that the cognitive conflation between its external 
enemy and restive minority was all but complete. ${ }^{97}$ This conflation would have devastating consequences once the war began, and Russian support for Armenians shot up to "high" levels. Recent research in political science backs this assessment: rather than a long-standing ideological conviction on the part of Ottoman leaders, it was "Russian, and later French, military and diplomatic support of the Armenians-rather than merely the cultural or religious difference between Armenians and Turks per se-that transformed the perception of this group in the eyes Ottoman ruling elites and set the stage" for the genocide. ${ }^{98}$

Overall, then, the "initial rapprochement between the CUP and Armenian nationalists during the Revolution of 1908 in the name of 'Brotherhood and Unity'" gave way to widespread suspicions that the Armenians were poised for a mass uprising, buoyed by the Ottomans' losses of its European provinces as well as increased contact between Russian forces and Armenian dissidents. ${ }^{99}$ This fear, often exaggerated but still deeply held, led to drastic and genocidal measures when the level of external threat ramped up with the Ottoman entry, and disastrous losses, in World War I.

\section{The Escalation to Genocide}

By the end of 1914, the territorial and ideological changes in the Ottoman state, alongside the scarcely concealed alliance between Armenian nationalists and Russia, increased the baseline level of threat the center perceived from the Armenians. Peaceful reforms were now anathema, the prospect of an Armenian state or anything approximating it deemed impermissible. ${ }^{100}$ Gone were the days when the Young Turks considered Armenians a valuable and integral part of the tapestry of the revolutionary state. Now, Armenian identity was deemed directly opposed to the Ottomans' concept of nationhood. Furthermore, the Young Turks' optimism about their external environment had given way to the cold realization of their empire's vulnerability.

With the outbreak of the Great War, which heightened considerably the baseline threat the Armenians posed to the Ottoman Empire, the idea of making concessions that could lead to an Armenian state was out of the question. The security consequences of such an eventuality were simply too grim, as Enver Pasha noted:

In my opinion this is a very big mistake. If today in the Caucasus a small Armenia possessing a population of five to six hundred thousand and sufficient territory is formed, in the future this government, together with the Armenians that will come mainly from America and from elsewhere, will have a population of millions. And in the east we will have another Bulgaria and it will be a worse enemy than Russia because all the Armenians' interests and ambitions are 
in our country. Consequently, in order to remove this danger, the formation of even the smallest Armenian government must be prevented. ${ }^{101}$

The Turks were wary of the prospect of an Armenian state not just because Armenians themselves could cause them great harm in the future, but also because they could partner with others to the same end. For instance, there were concerns expressed that the British and others would use Caucasian Armenia as a base from which to drive out the Turks from eastern Anatolia. ${ }^{102}$ Even their decision-making at the end of the war betrayed Ottoman leaders' central preoccupation with the security implications of an Armenian state, when in a bizarre diplomatic volte-face, they supported its creation, on one condition: that ethnic Georgians and Azeris join them. This was because at that point, it was clear an Armenian state would come into existence; the only question was its composition. Behind the Ottomans' seemingly curious policy was a transparent aim, to weaken the Russian state from within. More to the point, where the Armenian state was essentially a fait accompli, the Ottoman diplomatic corps attempted to limit the size of the Armenian army, a signal that it was concerned with the security ramifications of Armenian independence. ${ }^{103}$

Before an Armenian state became a cartographic fact, however, the Ottoman Empire used a strategy of "collective repression" in 1914-15 to forestall its creation. This was because Armenian nationalists were supported at "high" levels by Russia during World War I. In other words, Ottoman leaders perceived that cooperation between Russia and the Armenians extended to them fighting side by side. Armenians' collusion with Russia meant that when the war began, they were targeted for extermination and deportation by the Ottoman authorities. During the spring and summer of 1915, both materialist and emotional implications of "high" third-party support were operative. The threat of Armenian collaboration and rebellion, especially given the community's location, ensured a tougher fight for the Ottomans against the Russians. Additionally, "the collective stereotypes of Armenians as grasping and mercenary, subversive and disloyal, turned them into an alien and unsympathetic category that then had to be eliminated." 104 Armenians had been the subject of massacres and violence before, most notably under the regime of the sultan, ${ }^{105}$ but the level, intensity, and length of time that they were made victims of genocidal policy was something unprecedented. At the center of it all was the Armenian-Russian partnership, and what it meant for Ottoman security. Below, I develop this argument in four steps.

First, the circumstances under which the genocide unfolded, particularly relating to Russian-Armenian collaboration, need to be closely examined. Second, a look at Ottoman leaders' statements and quotes captures their decision-making processes at the time. Third, the timing of deportations is indicative of the importance of the external peril facing the Empire. Fourth, 
the location of the major Armenian population centers, on the path of oncoming Russian or British thrusts, alarmed the Ottomans because it exposed their vulnerable supply lines and threatened collaborationist attacks. Taken together, these items constitute strong evidence for the argument that the Armenian genocide was directly related to the Ottomans' external security concerns.

Before we proceed, it is important to note two points. First, the question of whether the Armenian genocide was "preplanned" is contested in the historical literature. There are essentially two views. One claims that the genocide was planned and prepared for before the war broke out, and that the Ottoman authorities waited until the war only to use it as an excuse to carry out a long-held preference for the extermination of the Armenian nation, perhaps to create "space" for a Pan-Turkic empire. This is a view most often, but not exclusively, ${ }^{106}$ expressed by scholars sympathetic to Armenia. ${ }^{107}$ The other side argues that though the Armenians were subject to much violence and coercion before World War I, the policy of genocide and deportation arose only as direct responses to conditions of international war. I side with the latter group, and in the following pages show that this side has greater claims to historical accuracy.

The second note to make is to reiterate that an explanation for genocide is in no way commensurate with its justification. My purpose in this chapter is to understand the factors that led to the Ottoman genocide of Armenians, but it is certainly not to suggest that such strategic decisions are moral or excusable under any circumstances. There simply can be no justification for the slaughter of a million noncombatants. Even if one grants the Ottoman state the concession that there existed security exigencies concerning the Russian-Armenian alliance, the reaction to those exigencies was wildly disproportionate. As one historian notes, the allegations of disloyalty and treason aimed at the Ottoman Armenian community were "wholly true in as far as Armenian sentiment went, only partly true in terms of overt acts, and totally insufficient as a justification for what was done."108 Perhaps more important, the Ottomans' perilous security position in 1914-15, both externally and internally, was in large part its own doing: it joined the war of its own volition to fulfill revisionist aims despite its military and economic weakness relative to European powers, and through decades of vehemently resisting reforms that would improve the lot of its Armenian community, drove it into the arms of its longtime enemy, Russia. Cruelly, the most vulnerable actor in the Russia-Ottoman-Armenia triad was the one that bore the brunt of great power machinations.

WAR, COLLABORATION, AND GENOCIDE

Initially, the Ottoman Empire was neutral in the war, but the desire to oppose Russia was too great, given past hostilities. On October 20, 1914, 
Enver Pasha, as the minister of the navy, convinced Jamal Pasha to bombard Russian ports and ships with German ships. As a consequence, Russia declared war on the Ottoman Empire on November 2, 1914. The British and French followed suit on November $5 .{ }^{109}$ It would be the tenth time that the Ottomans and Russia were at war in two centuries, but this time, the former's traditional allies, Britain and France, were on the other side. Czar Nicholas II conveyed Russian war aims to the French ambassador: to expel the Turks from Europe, to bring Constantinople under a neutral administration, and to annex Armenia. ${ }^{110}$

Meanwhile, the Ottoman's central concern in the war was to reclaim lost territories and, more broadly, to reclaim its status as a great power-to fight off British and French control of its fiscal policy and European violation of its sovereignty. The Armenian reform agreement signed just the previous year was particular cause for angst, and overturning it, or ignoring it altogether, was one of the driving decisions to enter the war. ${ }^{111}$ Barely a month after the Ottomans' entry into the war, the two European inspectors required by the Mandelstam Plan, L. C. Westenenk from the Netherlands and Nicolai Hoff from Norway, were sent home, and the plan as a whole was torn up, by way of an imperial rescript. ${ }^{112}$

Once the war began, the Armenian community was dealt with on the basis of security: would it help provide it, or prove to hinder it? Armenian representatives from all the vilayets, but particularly in the Caucasus, rejected the Young Turks' suggestions on cooperating during the war. ${ }^{113}$ Their refusal cemented the belief that Armenian nationalism was a proxy of European great powers and morphed into a stereotype of Armenians as collaborators. Upon the war's commencement, Ottoman leaders received reports from the provinces about Armenian collaboration with advancing Russian forces. One telegram from the Interior Ministry to the eastern provinces in August 1914 referenced "completely reliable reports to the effect that the Russians have, through the assistance of the Armenians in the Caucasus, incited the Armenians among us . . . additionally, they have brought weapons and munitions with the intent of depositing them at certain places along the border." Another cable to the eastern provinces evinced considerable concern with Armenian-Russian cooperation, requesting officials "investigate and report back soon . . . on how many Armenian families have as of now left for the Caucasus and whether or not there is such a revolutionary movement or sensibility as this is present among the Armenians living there or if it is limited."114 In November 1914, the government "was already requesting lists of those of its subjects who had voluntarily gone to Russia, as well as members of their families." 115

The feelings of suspicion and the belief that the Armenians were fifth columnists were widely held. One cartoon that appeared in a satirical Turkish paper during the war summed up the dominant view in this 
regard, showing one Turk questioning another about where he gets his news. "I do not need war news," the second Turk replied. "I can follow the course of the war by the expression on the faces of the Armenians I meet. When they are happy I know that the Allies are winning, when depressed I know the Germans had a victory."116 Certainly the Ottoman authorities had reason to believe that they would face a two-pronged attack, from both within and without. ${ }^{117}$ Though Armenians had valiantly fought for the empire in its various wars in the past, the level of Armenian desertions to, and collaboration with, invading Russian forces was rising. Particularly in eastern Anatolia, the Ottomans had justifiable fears of an Armenian revolt being tied to external threats. Up to thirty thousand Armenians formed bands, and were armed and trained across the border in Russia, before returning when the war began. ${ }^{118}$ To cite an example of the eagerness with which the Russians and Armenians embraced each other, the czar traveled to the Caucasus to make plans for Russian-Armenian cooperation in preparation for the winter conflict between Russian and Turkish forces in the region. The president of the Armenian National Bureau in Tiflis said in response:

From all countries Armenians are hurrying to enter the ranks of the glorious Russian Army, with their blood to serve the victory of Russian arms... . Let the Russian flag wave freely over the Dardanelles and Bosporus. Let, with Your will, great Majesty, the peoples remaining under the Turkish yoke receive freedom. Let the Armenian people of Turkey who have suffered for the faith of Christ receive resurrection for a new free life under the protection of Russia. ${ }^{19}$

At the onset of the war, the czar also notably promised the Armenian catholicos Kevork V that "a most brilliant future awaits the Armenians" if they allied with the Russians against the Turks. ${ }^{120}$ In September, the czar told Armenians that "the eve of liberation from Turkey was nigh," and Russian military plans included the formation of "armed Armenian bands under military command in the Caucasus at Olty, Sarikamish, Kagysman, and Igdyr, and, in Persia, bands at Choi and Dilman under the authority of the Russian military and the Choi consulate." ${ }^{121}$ Within the specter of war, however, these promises of support from the Russian side and desertions from the Armenian side spelled disaster for the Armenians, since it completed the cognitive tying together of their cause with the Russians: perceptions of third-party support were locked at "high" levels.

It is important to note that Turkish accusations of desertions and Armenian soldiers passing over to Russian territory are corroborated by American, German, and Austrian sources, as well as prominent Armenian nationalists themselves, like Nubar. The historical record shows, among other instances, that the well-known Armenian partisan Andranik helped 
the Russian forces invading Saray, east of Van province, from Persian Choi, and that another group of Armenian volunteers joined the Russian forces in occupying Bayazid, in the north. ${ }^{122}$ In a cable from early February 1915, Ambassador Wangenheim conveyed to officials in Germany that "I constantly come up against an opinion among the Turks, which until now has not been refuted by the behavior of the Armenians, that if Turkey is defeated, the Armenian population would definitely join the winner's side."123

Young Turk leaders, then, "were convinced that all Armenians were potentially disloyal and likely to be pro-Russian." 124 Such ArmenianRussian collaboration was deeply concerning to Ottoman leaders-enough for Talaat, at the beginning of the war, to demand that Germany offer Russia parts of occupied Poland if it would translate into Russia's withdrawal from any part of the Ottoman Armenian vilayets. He also asked that the Germans evacuate parts of Flanders as a quid pro quo for the British to leave Iraq. ${ }^{125}$ At the same time, the Ministry of War created the Secret Organization for the purpose of dealing with security threats throughout the empire. One of the first tasks that the Secret Organization concerned itself with-in addition to the Greek community in western Anatolia-was how to disentangle the Armenian community in eastern Anatolia from the territory in question, owing to its proximity to Russia. ${ }^{126}$ Prominent members of the Armenian political community and intellectuals were to be closely monitored. ${ }^{127}$ In addition, the Ministry of War, under Enver's direction, also created a series of paramilitary youth groups, supplying them with arms and ammunition for the "defense of the fatherland." Enver also ensured that the CUP maintained greater control of the military than previously by culling the old regime of officers-he fired eleven hundred in January 1914 alone-and promoting hundreds of loyalists to high-ranking positions. ${ }^{128}$

The killings of Armenians started in the late summer of 1914. In the border regions of the Caucasus and Persia, Armenian property was looted and plundered, and Armenian men were rounded up and killed, by militias and small bands of forces. At that point, the killings had not yet attained the massive scale they would later. Rather, the genocide proper began in the spring of 1915 as a series of massacres in sensitive border regions most vulnerable to external intervention. ${ }^{129}$ The killings then spread south and west from eastern Anatolia, where the largest share of the Armenian population lived. In all, more than 1 million Armenians died in the genocide, more than two-thirds of whom met their fate as a direct result of being deported. ${ }^{130}$ Most of the violence was carried out by paramilitary organizations and through secret orders. ${ }^{131}$

Balakian summarizes how the genocide unfolded:

Armenians were rounded up, arrested, and either shot outright or put on deportation marches. Most often the able-bodied men were arrested in 
groups and taken out of the town or city and shot en masse. The women, children, infirm, and elderly were given short notice that they could gather some possessions and would be deported with the other Armenians of their city or town to what they were told was the "interior." Often they were told that they would be able to return when the war was over. ...

A map of the Armenian genocide shows that deportations and massacre spanned the length and width of Turkey. In the west the major cities included Constantinople, Smyrna, Ankara, and Konia. Moving eastward, Yozgat, Kayseri, Sivas, Tokat, and Amasia were among the large cities of massacre and deportation. Along the Black Sea, Samsun, Ordu, Trbizond, and Rize were killing stations where Armenians were often taken out in boats and drowned. In the south, in historic Cilician Armenia, Adana, Hadjin, Zeitun, Marash, and Aintab were part of the massacre network. The traditional Armenian vilayets in the east-Sivas, Harput, Diyarbekir, Bitlis, Erzurum, Van-with hundreds of villages and dozens of cities, where the majority of the Armenian population of the empire lived on their historic land, were almost entirely depleted of their Armenian populations. ${ }^{132}$

The forced marches exacted such a high toll because they were through rough terrain in difficult weather, with no medical support or protection against marauders. ${ }^{133}$ First person testimony is sparse for obvious reasons, but some survivor's tales have made it through the test of time. One memoir, for instance, describes a typical scene following a deportation order:

As I now recall that day, there is a trembling in my body. The human mind is unable to bear such heaviness. My pen cannot describe the horrors. Confusion! Chaos! Woe! Wailing! Weeping! The father kisses his wife and children and departed, sobbing, encrazed. The son kissed his mother, his old father, his small sisters and brothers, and departed. Those who went and those who remained sobbed. Many left with no preparation, with only the clothes on their backs, the shoes on their feet, lacking money, lacking food, some without even seeing their loved ones. Already thousands of men had gathered in the appointed place, and like madmen, others were joining them. ${ }^{134}$

THE MINDSET OF OTTOMAN LEADERS IN 1914-15

Why did the Ottoman Empire commit genocide against its Armenians? Ottoman leaders were obsessed with the prospect of territorial loss, and the potential of Armenians to aid in their state's dismemberment by collaborating with Russia. The specific personalities behind the policies that led to genocide offer a clue as to its origins: by most accounts, Enver Pasha, the minister of war, and Talaat Pasha, the minister of interior, were behind the mass deportations, lending credence to the belief that the deportations were a security issue, rather than an ideological one. ${ }^{135}$ Unfortunately, it is 
difficult to ascertain the exact processes by which the triumvirate of Enver, Talaat, and Jamal made decisions because archival records within the Ottoman state were either lost or destroyed in a period of chaos. ${ }^{136}$ However, that these leaders consistently maintained both publicly and privately that their drastic measures against the Armenian population were primarily due to the wartime situation and the existential threat the state faced given Armenian-Russian collusion is instructive. Their particular emphasis on the threat posed by Armenians in their rear, as they faced the Russians in the Caucasus and the British in Palestine, suggests that the material effects of "high" third-party support were especially important. Alongside this material effect of Russian backing, Talaat's and Enver's statements also stress the emotional consequences of collusion that Armenians experienced: an angry and betrayed state.

Take, for instance, Talaat's warning to an Armenian representative in a moment of candor: "We will do whatever Turkey's interests demand, it is a matter of one's fatherland. There is no place for personal attachments. Do not forget how you jumped at our throats and stirred up the problem of Armenian reforms in the days of our weakness." ${ }^{137}$ Elsewhere Talaat stated that "it was deemed necessary, in order to avoid the possibility of our army being caught between two fires, to remove the Armenians from all scenes of the war and the neighborhood of the railways." ${ }^{\prime 38}$ After the Armenian uprising at Van, timed to coincide with the Russian invasion, Enver revealingly told Ambassador Morgenthau in a private meeting that

the Armenians had a fair warning of what would happen to them in case they joined our enemies. Three months ago I sent for the Armenian Patriarch and I told him that if the Armenians attempted to start a revolution or to assist the Russians, I would be unable to prevent mischief from happening to them. My warning produced no effect and the Armenians started a revolution and helped the Russians. You know what happened at Van. They obtained control of the city, used bombs against government buildings, and killed a large number of Moslems. We knew that they were planning uprisings in other places. You must understand that we are fighting for our lives ... and that we are sacrificing thousands of men. While we are engaged in a struggle such as this, we cannot permit people in our own country to attack us in the back. We have got to prevent this no matter what means we have to resort to. It is absolutely true that I am not opposed to the Armenians as a people. I have the greatest admiration for their intelligence and industry, and I should like nothing better than to see them become a real part of our nation. But if they ally themselves with our enemies, as they did in the Van district, they will have to be destroyed. ${ }^{139}$

As Enver said, treatment of secessionist minorities in war time obeyed different logics than during peace, when the external threat was not as significant: "During peace times we can use Platonic means to quiet Armenians 
and Greeks, but in time of war we cannot investigate and negotiate. We must act promptly and with determination." On another occasion, he reiterated the importance of war and external security on their decisionmaking process: "Our situation is desperate, I admit it, and we are fighting as desperate men fight. We are not going to let the Armenians attack us in the rear." ${ }^{140}$ In a cable to most of the Ottoman provinces, Talaat echoed this logic, writing that "the objective that the government expects to achieve by the expelling of the Armenians from the areas in which they live and their transportation to other appointed areas is to ensure that this community will no longer be able to undertake initiatives and actions against the government, and that they will be brought to a state in which they will be unable to pursue their national aspirations related to the advocating for $\mathrm{a}[\mathrm{n}$ independent] government of Armenia." 141

Talaat stuck to similar themes in conversations with Morgenthau: "These people refused to disarm when we told them to. They opposed us at Van and at Zeitoun, and they helped the Russians. There is only one way in which we can defend ourselves against them in the future, and that is just to deport them." ${ }^{142}$ He later drew a direct connection between the Armenian relationship with the Russians on the one hand, and the Turkish performance in the war: "They have openly encouraged our enemies. They have assisted the Russians in the Caucasus and our failure there is largely explained by their actions. We have therefore come to the irrevocable decision that we shall make them powerless before this war is ended." ${ }^{143}$ After a private meeting with Talaat during the war, U.S. ambassador Morgenthau reported that "he [Talaat] explained his [Armenian] policy on the ground that the Armenians were in constant correspondence with the Russians." 144 Enver was similarly forthcoming with Morgenthau: "If the Armenians made any attack on the Turks or rendered any assistance to the Russians while the war was pending, [I] will be compelled to use extreme measures against them." ${ }^{145}$ Those words proved to be prophetic. ${ }^{146}$

TIMING OF GENOCIDE: MOMENT OF NATIONAL PERIL

One could reasonably object to the above with the proposition that Enver and Talaat were employing justificatory rhetoric for decisions that had little to do with security. If their statements were mere window dressing, however, then how is one to explain that the timing of the genocide coincided with a security emergency for the Ottomans?

Indeed, it was only by the summer of 1915 that a clear and coherent policy of empirewide killings and massacres even developed. The deportations, the single leading cause of death of Armenians in World War I, began a full seven months after Turkey's entry into the war. ${ }^{147}$ Generally speaking, the policy of genocide was instituted only in a period of national peril, 
between April and June 1915, when the Ottomans were on the back foot in the war. As one international relations scholar notes, "The radicalization [of Ottoman policy] seems to have occurred in large part in response to the Turks' rapidly deteriorating military situation." 148 Part of the Turks' worsening security was down to their own strategic myopia-Enver Pasha, for instance, chose the wintertime in 1914-15 to launch an attack on Russia's Caucasus region. Despite some initial success, he lost more than seventyfive thousand out of ninety thousand men, mainly due to the weather. Moreover, the Russian general Yudenich foresaw Enver's encirclement strategy, was prepared adequately, and dealt a crushing blow to Enver's forces. ${ }^{149}$ It must be noted, however, that the Russians were aided in considerable part by six Armenian volunteer units, of eight to ten thousand men each, who were familiar with the terrain, and were useful as scouts, guides, and advance guards. After the Battle of Sarikamish, which effectively ended the Turkish fight in the Caucasus, the Armenian units received high praise from Russian military commanders and even the czar. The loss at Sarikamish, and the wider loss in the Caucasus generally, was pinned on Armenians by Enver-even if his own decision-making was largely to blame. ${ }^{150}$ Regardless of culpability for the loss, the bottom line was that "the disaster at Sarikamish left just some fifty-two thousand Ottoman soldiers spread over a six-hundred-kilometer front facing the much better equipped Russia's Caucasus Army with roughly seventy-eight thousand effective combatants." ${ }^{151}$ In addition, immediately after Enver's failure in the Caucasus, the Ottoman army's campaign in Persia failed. Enver's brother in law, Jevdet Bey, was compelled to withdraw and retreat from Tabriz. ${ }^{152}$ The devastating battlefield losses in January 1915 planted the first seeds of what was to come. ${ }^{153}$ As a result of the defeat, and in conjunction with earlier desertions, Armenian soldiers were disarmed and Armenian villages were massacred by retreating Turk forces, ${ }^{154}$ the first set of large-scale massacres against Armenians during the war.

More generally, the spring of 1915 was a time of considerable danger for the Ottoman state, since it faced invasion on three fronts: the British and French in the West, at the Dardanelles; the British in the South, in Iraq; and the Russians in the east. ${ }^{155}$ In February the Royal Navy launched the first attack on the Dardanelles. Britain and France had planned an amphibious assault, aimed at taking the Dardanelles on the way to Istanbul, establishing a "critical supply route to Russia." 156 Concomitantly, the allies were bombarding, and later landing, on the beaches north of Çanakkale. These allied movements "led the Unionists to believe that the end of the empire was certainly at hand." 157 Ottoman forces were also compelled to retreat from the Suez Canal in early February, while the British Indian Army attacked the Ottomans through central Iraq, occupying Basra in November. All the while, the weakness and lack of development insofar as the Ottoman economy and infrastructure was concerned only exacerbated the status 
quo, since it meant that provisions from the capital to the periphery declined both in quality and quantity. 158

March 1915 was a turning point, with the Dardanelles attack in the foreground along with a Russian move toward Van. Concurrent with "the British coming up from the south, and the British and French landing at Gallipoli in April," the government prepared to move the capital from Istanbul to the east and make a "last stand" in the Anatolian interior. ${ }^{159}$ As one scholar puts it, "The Ottoman Empire was being pinched in three directions at once. The Fourth Army in Syria and the Sixth in Mesopotamia were both in danger of being cut off owing to partisan attacks . . . in the worst position of all, however, was the Third Army facing the Russians, who were advancing against a beaten and battered enemy on both the northern (Erzurum) and southern front (Dilman-Van)."160 These developments "cast panic into the hearts and minds of the CUP leaders" because they reaffirmed their fears of a "nightmare scenario in which potential Armenian disloyalty would pave the way for an Allied incursion into Anatolia." Consequently, the Special Organization-in charge of irregular paramilitary units-was reorganized and expanded to deal with the increasing threat. ${ }^{161}$ As Suny argues, Ottoman leaders were both fearful and angry: afraid of the future of their state and angry "at the perceived betrayal metamorphosed into hatred of those who by their nature were devious and treacherous." 162

Deportations were a result of this toxic mix of fear and anger. On April 8, there were "targeted" deportations from Zeytun and Maras, both sites of Armenian uprisings. On April 24-25, the night of the Allied landings at Gallipoli, Armenians in Constantinople were arrested and, more important, Talaat and Enver issued decrees ordering the reduction of Armenians to less than 10 percent of the population in frontier districts and frontline areas. On May 2, after the rebellion at Van, the entire Armenian population of Van was removed. Later, these relatively ad-hoc measures, gave way to "more systematic overtones." ${ }^{163}$ First, the deportees from Zeytun, Maras, and Van were rerouted from the original destinations to Urfa and Aleppo, before it was decided to send them even further south, to the Syrian desert. Then, Talaat issued his famous decree of May 31, which called for the deportation of Armenians in the six eastern provinces away from frontline areas, to areas at least twenty-five kilometers away from rail lines. In June and July, Armenian uprisings behind Ottoman lines led to the deportation net being thrown wider still: it now included Samsun, Sivas, Trabzon, and the port cities on the Mediterranean, Mersin and Adana. ${ }^{164}$

The timing of the first deportation orders, and their ensuing escalation, lends strong support to the argument that external security considerations were a key driving force for the genocide. It was only when the Ottoman Empire was on the back foot in the war-after disastrous losses in the winter of 1914-15 and the prospect of being pinned between three fronts in 
March-April 1915-that Ottoman leaders began their policy of "collective repression" against their Armenian community. That the timing of this escalation so closely coincided with wartime fears of the end of the Ottoman Empire draws into sharp question the view that the Armenian genocide was unrelated to security concerns.

\section{LOCATION OF DEPORTATIONS: SUPPLY}

\section{LINES AND ALLIED INCURSIONS}

Talaat stated that "if war is declared, Armenian soldiers will take shelter on the enemy side with their arms. If the Ottoman army advances, [they will] remain inactive, if the Ottoman army retreats, [they will] form armed bands and hinder transport and communication" (quoted in Bloxham 2003, 163). There is considerable evidence that the Armenians provided exactly such support, impeding the Ottoman war effort. The threat of Armenian collaboration was especially problematic because they were concentrated in locations that alternately posed a threat to Ottoman supply lines, or could serve as springboards for landings and incursions by the Russians, British, and/or French. As such, even the slightest suspicion of collusion was enough to radicalize Ottoman leaders during wartime-the stakes were simply too high, and the costs of being insufficiently concerned too weighty, to contemplate half measures.

The geographic logistics of the Ottoman war effort are crucial when understanding the roots of the genocide. Erickson sums up the Ottoman predicament:

The Ottomans were fighting the Russians on the Caucasian frontier, and the British in Mesopotamia and Palestine. The lines of communication supporting those Ottoman fronts ran directly through the rear areas of the Ottoman armies in eastern Anatolia that were heavily populated by Armenian communities and, by extension, by the heavily armed Armenian revolutionary committees. Importantly, none of the Ottoman armies on the fronts in Caucasia, Mesopotamia, or Palestine were self-sufficient in food, fodder, ammunition, or medical supplies and all were depending on the roads and railroads leading west to Constantinople and Thrace for those supplies. Moreover, none of these forces had much in the way of prepositioned supplies available and all required the continuous flow of war material. The Armenian revolutionary committees began to attack and cut these lines of communication in the spring of $1915 .{ }^{165}$

Rebellious Armenians threatened Ottoman prospects in war because of where the war was being fought and where the Armenians were concentrated: at the rear of the major fronts the Ottomans were fighting on. As Suny notes, "The Caucasian front was the longest front for the Ottomans and the 
most difficult to defend and supply. The Ottoman-Russian border stretched 280 miles, but the zone of fighting extended twice that distance, deep into Ottoman territory and Persia," a "frontier region with porous borders."166

Armenian regions posed special dangers to the empire's rail system, the Ottomans' "'Achilles Heel' because it served almost the entire logistics needs of the three Ottoman field armies in the Caucasian, Mesopotamian, and Palestinian theaters of operations (the Third, Sixth, and Fourth armies respectively)." 167 The fact that Talaat's deportation orders emphasized Armenians be resettled "at least twenty-five kilometers away from the Baghdad railway lines running to the frontier as well as away from other railway lines" is instructive: such a distance would be near impossible to traverse safely in one night's darkness, suggesting that security was a key imperative for Talaat's orders. ${ }^{168}$ The region of Dortyol, for instance, was a pressing concern both because it was located on the Mediterranean, and thus inviting to Allied incursions, and also because it was where the so-called "BerlinBaghdad" railway split. Troubles in Dortyol occupied the attention of security bulletins and cables from Enver and Talaat in March and April in 1915, resulting in the deportation of Armenian communities from Dortyol and the nearby Alexandretta, Adana, and Bilan districts. In addition to the rail network, sizable Armenian populations were located on or close to the main road links from Sivas to Erzurum, which supplied the Ottoman Third Army in the Caucasus. ${ }^{169}$ The relative importance of these supply lines increased in the aftermath of Enver's loss at Sarikamish, which moved the front to the lowland Urmia region. Urmia lay at the intersection of the Ottoman, Russian, and Persian empires, "ground zero in the Russo-Turkish espionage and propaganda wars over the loyalties" of Kurds, Armenians, and Assyrians. ${ }^{170}$ As such, Ottoman leaders' deportation orders in the spring of 1915 could legitimately be seen as securing the "tactical rear of the Third and Fourth Armies" in the Caucasus and Mesopotamia/Palestine (see map 2). ${ }^{171}$

Aside from these general concerns about supply lines and railroads, Armenian uprisings in several prominent locations catalyzed Ottoman paranoia and fear, as the massacres in Van illustrate. Van was a crucial strategic location, important for its connection to Russian military plans, as well as its ability to rise up militarily based on it being armed and trained. It could be used by Russian forces launching into Mesopotamia and interior eastern Anatolia from Persia, or by the Turkish forces in the opposite direction. ${ }^{172}$ It was a significant military pivot, and its importance grew only after the defeat at Sarikamish. Specifically, as the center of gravity of the Ottoman-Russian war shifted south from the winter to the spring, the Ottoman defeat at Dilman in late April increased the significance of Van, which was now "directly in the path opened up by the Russian victory at Dilman." ${ }^{173}$ Van had a dense Armenian population, and a significant Armenian Revolutionary Federation presence, one that had established prewar connections to the Russian consulate. Demographically, the Armenian 
population was greater than the Turkish and Kurdish population combined, further increasing its importance. ${ }^{174}$

In the spring of 1915, the CUP correctly anticipated a massive Allied offensive: while Russia was preparing to launch aggressively in the Caucasus, the British and French were expected to stage landings at Gallipoli on April 25. Turkish commanders had often spoken about the threat of insurrection in Van, and when news spread of Armenian collaboration with Russian forces, Ottoman forces turned their attention to the region. As preemptive measures, the authorities carried out mass arrests in the Armenian parts of Van on April 24, similar to the mass arrests carried out in Trebizond on April 19, which immediately preceded the Russian attack on the port of Kerasond/Giresun on April 20. ${ }^{175}$ These arrests represented the first step in the escalation in Van. Along with the arrests, the government demanded that the city hand over four thousand Armenian men for the army's labor battalions. Van's leaders surmised that those men would ultimately be killed, since that was the usual fate of Armenians in labor battalions all over the empire, and asked that the men instead be used for combat duty, but their request was refused. The Armenians then counteroffered with a proposal of handing over four hundred men, with the justification that the rest were exempt due to payment of a tax, but Jevdet Bey, now the governor of Van province, refused to budge. ${ }^{176}$ Concomitant with the mass arrests, the Armenian community in Van staged an uprising. On April 20, 1915, four thousand Armenian fighters fired at police stations, set alight Muslim houses, and set up a barricade behind which they stayed on the defensive. An additional fifteen thousand Armenian refugees soon joined the rebellion. Turkish forces suffered huge losses in trying to stamp out the rebellion and inflicted mass casualties of their own. The fighting went on for a month. ${ }^{177}$

With their ammunition running low, the Armenians were saved by the advancing Russian army, which forced the retreat of the Turkish units. The Russians' advance itself was aided in considerable part by both Russian and Ottoman Armenians. Armenian units were especially useful as bands of shock troops, as well as guides to the area, and were crucial to the Russian advance. The entire episode-from the initial insurrection to the joint invasion of Van - was believed to be a coordinated rather than a random coincidence, even by foreign diplomats on the scene sympathetic to the Armenians. This, then, crystallized for the Turkish state the belief that the Armenians were traitors against whom strong action would be justified. ${ }^{178}$

During the conclusive days of the fighting in Van, the Ottomans brutally followed the Russian line of attack with massacres and deportations. As U.S. ambassador Morgenthau cabled in June 1915, "Because Armenian volunteers, many of them Russian subjects, have joined Russian Army in Caucasus and because some have been implicated in armed revolutionary movements and others have been helpful to Russians in their invasion of 
Van district, terrible vengeance is being taken." ${ }^{179}$ German diplomats also backed this interpretation. On May 8, Ambassador Wangenheim cabled that "despite efforts by Armenian circles to diminish the significance of the riots which have broken out over the past few weeks in various places or to put the blame on the measures taken by Turkish authorities, there are increasingly more signs that this movement is more widespread than presumed up to now and that it is being encouraged from abroad with the help of Armenian revolutionary committees . . . it cannot be denied that the Armenian movement has taken on a worrying character over the past few weeks, which has given the government cause to introduce severe repressive measures." ${ }^{180}$ As Reynolds notes, "At the same time as the Van rebellion was unfolding, the Russians were entering from the east, the British pushing on Baghdad from the south, and most ominously, the British and French were storming ashore at Gallipoli. The simultaneous attacks stretched the wobbling Ottoman army to breaking point."181 Van was a crucial step in the escalation to genocide mainly because it confirmed the worst suspicions of the Ottomans, and that too at a strategically vulnerable time in the war. ${ }^{182}$ One historian of the genocide calls the Van insurrection the "turning point" as far as the deportations and massacres were concerned. ${ }^{183}$

Van was not the only geographic area where massacres and deportations followed the external security threat. One can also consider Cilicia. At the end of March 1915, the Ottomans feared that the Russians would make incisions through eastern Anatolia in a bid to capture the port city of Alexandretta/Iskenderun, because it represented the shortest route to bisect the empire and acquire a Mediterranean port. Indeed, the Russians themselves had advertised this strategy before the war. The Armenian population in Cilicia had a complicated history with respect to inviting outsider intervention to help their cause, and Ottoman authorities claimed that an uprising was to be timed to coincide with the Russian invasion. Some historians have dismissed those claims as pure propaganda, but Nubar was in contact with the British military in Egypt and floated the idea of the Armenian community in Cilicia being a bridgehead for invading Entente forces. The British had asked the Armenians to "revolt to make things more difficult for the government, and support the British by hindering [the government's] efforts to mobilize." ${ }^{184}$ Cilicia was consequently targeted with massacres and deportations. ${ }^{185}$

There was a similar story in Zeytun, where the fear of desertions and collaborations fed into the stereotype of Armenians as the "enemy within."186 Before the war even began, there were signs of organized revolt; Armenians in Zeytun refused to be conscripted in the Ottoman Army and organized a corps of volunteers in order to disrupt Ottoman lines of communication. During the war, in May 1915, there was a second uprising in Zeytun, an episode which led to the formal introduction of deportation laws on 
May 27, with the purpose of drawing Armenian populations away from strategically important areas. ${ }^{187}$ As Enver told Ambassador Morgenthau, "We shall not permit them to cluster in places where they can plot mischief and help our enemies. So we are going to give them new quarters." ${ }^{188}$ This was essentially the final nail in the Armenians' collective coffin, since the general deportation orders spelled doom for the community. By June, the deportations were in full swing across the empire; only 20 percent of the deportees would even reach their desert destinations. ${ }^{189}$

The case of Adapazari, in northwest Anatolia, where the deportations began in July 1915, also followed this trend. Enver and Talaat believed that an Armenian rebellion was being planned in conjunction with an expected Russian landing on the Black Sea. "Talaat's memoirs, as well as other wartime publications, offered evidence of escalating guerilla activity on the provincial border between Bursa and Izmit, as well as the discovery of hidden weapons caches throughout the region. Indeed, several secret telegrams confirm cases of Armenian bandit activity in Bursa and Izmit in 1915 and 1916," though it should be noted that these reports were filed after the deportations had already begun. ${ }^{190}$

That the massacres and violence were proceeding in step with the external threat is shown not just by where the violence occurred but where it failed to occur. ${ }^{191}$ For example, between March 5 and March 17 in 1915, there was to be a joint British and French attack on the Dardanelles, to relieve pressure on Russia's forces in the Caucasus. As a preemptive measure, authorities were given orders to carry out deportations-which, we must remember, almost always meant death for the deportees ${ }^{192}$-in the region between Constantinople and the new provisional government base in Eskishehir. The point was to ensure that the Armenians did not join invading forces and conduct reprisal operations against the population transfer of citizens, as the Ottomans wished to move their capital from Constantinople given the expected Anglo-French attack. But when the anticipated breakthrough did not occur, the population transfer, and attendant massacres, also failed to materialize, suggesting that "Armenian policy was still contingent on the course of the War, and was not fully proactive or general across the empire."193

Certainly once the genocide achieved its own momentum, it bore less of a relationship to an external threat, especially after June 1915. It is also true that the cleansing of Armenians served the purpose of creating a more ethnically homogenous territory on which to base the modern Turkish state. ${ }^{194}$ Finally, there is little doubt that the Ottoman leadership could have arranged for deportations that did not necessarily result in mass death, but chose not to, almost assuredly due to a vicious antipathy against Armenians. ${ }^{195}$ But these qualifications aside, the spread of violence in 1915 shows that the escalation to deportations and massacres occurred as preemptive measures against a foreign military threat. "High" levels of Russian support 
for Armenian nationalists resulted in a tougher fight for the Ottoman Empire, owing primarily to Armenians' location and potential for insurrection, as well as angry and emotional leaders bent on vengeance. As German ambassador Wolff-Metternich reported after a conversation with Talaat in late 1915, "In the districts on the Russian border and near Aleppo, mass displacements had been necessary on the grounds of military security. A Russian-engineered large-scale conspiracy among the Gregorian Armenians in the border areas and near Aleppo had been discovered. Attacks on bridges and railways had been planned. It had been impossible to single out any individual culprit from the masses of these people. Only the deportation of the whole could ensure security."196

Moreover, in addition to the direct effects of collaboration, the indirect effects were important for external security too. The very existence of Armenian revolts in the empire meant that Turkish forces were often withdrawn from the front to deal with the uprisings, thus rendering them even more vulnerable to the external threat. ${ }^{197}$ For example, the rebellion in Van forced the Turks to reposition forces from strategically vulnerable campaigns in the Caucasus region and Persia to suppress the insurrection, fueling the belief that the Armenians were causing them considerable losses in the war. ${ }^{198}$

When the violence took place, where it took place, and where it did not take place-each of these factors supports Enver and Talaat's claims that the Armenian genocide was a product of external security considerations. The Ottoman Empire escalated to deportations only at the height of its external vulnerability, after battles at Sarikamish and the Dardanelles. Its policies were first enacted in those areas most vulnerable to Armenian sabotage and collaboration with oncoming Russian forces and were not executed where the external threat was deemed less important. The Ottoman Empire used a policy of collective repression against its Armenian community because of "high" levels of support from Russia, whose men often fought alongside or in sequence with Armenian bands, in a war that threatened the very existence of the state. Because this war and the RussianArmenian alliance closely succeeded the Balkan wars and the Russiandictated Mandelstam Plan, which cemented CUP beliefs that the Armenians were both a short-term and long-term threat to Ottoman security, the Armenians were targeted with genocide.

Scholarly consensus supports these views. According to Holquist, when it came to the slaughter of the Armenian population, "Russia's role-both in terms of intended and unintended consequences-was greater than that of any other party, aside from the CUP itself."199 As Bloxham notes, "The stereotype of Armenians as proxies of the Great powers in peacetime was extended into a stereotype of military collaboration during warfare: the 'inner enemy' and the 'outer enemy' were now fully merged in the Ottoman mind." ${ }^{200}$ Even those scholars that believe the genocide was "premeditated" 
concede the importance of the external security angle, as Kirakossian does when he writes that the Young Turks "were positive that in the forthcoming war the Armenians would become a threatening force in the enemy camp and considered it urgent to prevent them from taking unified action."201

Generally, Western scholars maintain that the deportations and massacres were not an a priori plan of action, but rather a result of a series of more limited measures that culminated in genocide. ${ }^{202}$ They were instituted because of the "mortal danger from without" that the Ottomans faced, in combination with Armenian collaboration. ${ }^{203}$ Gwynne Dyer, one of the foremost historians on the genocide, puts it thusly:

there was a genuine, though mistaken, belief among the Ottoman leaders in Istanbul that there was a deliberate and coordinated Armenian uprising in the East, with Empire-wide ramifications....

When more work is completed on the period, I believe historians will come to see Talaat, Enver, and their associates not so much as evil men but as desperate, frightened, unsophisticated men struggling to keep their nation afloat in a crisis far graver than they had anticipated when they first entered the war (the Armenian decisions were taken at the height of the Dardanelles), reacting to events rather than creating them, and not fully realizing the extent of the horrors they had set in motion in 'Turkish Armenia' until they were too deeply committed to withdraw. ${ }^{204}$

Armenian historians often claim that the deportations were a result simply of anti-Christian nationalism, but they are unable to explain why the Young Turks "cast both Muslims (Turkish-speaking or otherwise) and Christians in the same sinister light." 205 There simply does not exist strong historical evidence to suggest that before the war broke out, the Ottoman state planned for or wished to carry out genocide. In northwestern Anatolia, for instance, "CUP policies towards Armenians were intertwined with aims that were more operational in nature than ideological. The logic encased within state directives from this period emphasizes, above all things, the need for security within this critical region." ${ }^{206}$ As Mann sums up, initially the policy of forcible deportations "was designed to move potentially disloyal Armenians away from the theater of war so that they could not interfere with it." 207

\section{Alternative Explanations}

The main theoretical alternatives to mine cannot explain why the Ottoman Empire went from a policy of peaceful concessions to genocide. The reputation argument would predict more violence earlier in the Young Turks' tenure to establish a deterrent; in this case, the opposite took place. The argument for veto points, meanwhile, cannot explain the observed 
variation because the Young Turks' increasing centralization of power meant that there were fewer veto points to stop their offering concessionshad they wished for such a course. Under conditions of a low number of veto players, the domestic-institutions argument would expect the possibility of concessions to be negated by their incredibility to the secessionists due to the absence of veto points. However in this case, the leadership did not even consider such a concessionary policy, let alone desire it.

The principal competing context-specific explanation-that the Armenian genocide was "preplanned" sometime between 1910 and 1912-does not stand up to historical scrutiny. Scholars who wish to make this case rely on "secret" schemes and speeches given at the CUP congresses in 1910 and 1911, records for which do not exist. Notwithstanding the CUP's less pluralist nature over time-there was increasing talk of "Turkifying Armenians" - this view does not imply an intent to murder an entire community. ${ }^{208}$ As Bloxham states, "Despite the great deterioration of CUPArmenian relations, there is little evidence that a policy physically to destroy the community was forged prior to the First World War." 209 Scholars from the "preplanned" camp overstate the consistency of Young Turk policy between 1908 and 1915; their repeated efforts to find the proverbial smoking-gun evidence of orders for extermination of a people does not convince. ${ }^{210}$ Moreover, the very notion of a single turning point in the fate of the Armenians is problematic from a historiographical perspective, since rather than resulting from one decision on a given date, the genocide unfolded cumulatively as a process, or "cascading sequence of events."211 "Pre-planned" scholars' approach tends to be teleological" as Mann notes. "Early events, early decisions are too often read back from the ghastly known end result." ${ }^{212}$ These analysts employ as a starting point the final destruction of the Ottoman Armenian community and works backward to locate "violent expressions in the perpetrators' early speeches and writings, treating them as a 'serious declaration of intent.'"213 It is difficult to accept for some that such a far-reaching set of decisions could be made on a relatively contingent basis, without any grand purposes of social engineering behind it and affected primarily by the ebbs and flows of war, but the historical record suggests that is exactly what happened.

The theoretical framework employed in this book goes a long way in explaining variation in the Young Turks' strategy to deal with the so-called Armenian question. When they first ascended to power, the Young Turks forwarded a more universalist, Ottoman identity for all subjects of the empire and dealt with Armenian demands peacefully. The indifferent identity division, combined with a general optimism about the future of the modernizing Ottoman state, allowed for a policy of negotiations and concessions, reflected in the support they got from Armenian revolutionary parties. 
However, between then and 1915, two major changes occurred from the regime's perspective. First, Armenian demands were now cast in a more threatening light-since they were the only main Christian community left in the empire, their demands now threatened the ideational basis of the new, more narrowly defined Turkish nationalism of the empire. That is, the identity division between Ottomans and Armenians became "opposed." Additionally, a series of territorial losses changed the erstwhile optimistic outlook of the Ottoman leadership to a more insecure one. This meant that the prospect of a future Armenian state suddenly assumed graver security implications. Second, World War I, and in particular, its alliance patterns, which saw Russia against the Ottoman Empire, threatened the very existence of the Ottoman state. This external threat was given a considerable boost, both in reality and in perception, by Armenian nationalists, who fought alongside Russian forces. Because the level of third-party support they enjoyed was "high," there were to be no distinctions drawn between the Armenian "citizens" and the foreign enemy of Russia. As far as the regime was concerned, Armenians and Russians were one and the same. As such, when the state's security was at its bleakest, in the spring of 1915, the vicious policy of deportations was instituted across areas of the empire deemed most vulnerable to external intervention. 